https://doi.org/10.5719/aub-g/68.1/10

\title{
DEMOGRAPHIC TRANSFORMATIONS AFTER 1990 IN ROMANIAN SMALL AND MEDIUM-SIZED INDUSTRIAL TOWNS
}

\author{
ANDREEA-LORETA CERCLEUX ${ }^{1}$, FLORENTINA-CRISTINA MERCIU ${ }^{1}$, \\ ELENA BOGAN ${ }^{2}$, GEORGE-LAURENTIUU MERCIU ${ }^{3}$
}

\begin{abstract}
The paper is focusing on the analysis of the demographic transformations produced gradually inside the small and medium-sized industrial towns from Romania with the transition to the capitalist economy started in 1990. In order to highlight these changes, negative in general, the analysis takes into account the following indicators: natural balance, net migration, ageing population and demographic dependence rate, based on the economic causes that generated quantitative and qualitative changes in the population structures. The values of these indicators are investigated and discussed in the results section, including establishing connections between them, respectively chain effects and perspectives in time.

Keywords: demographic changes, small and medium-sized industrial towns, Romania.
\end{abstract}

\section{Introduction}

The small and medium-sized towns are affected nowadays by different phenomena and processes, as deindustrialisation, metropolisation or different territorial reforms (Cepoiu, 2009; Antonescu, Popa, 2012; Cercleux, 2016; Ciommi, Zambon, Salvatti, 2019; Cercleux et al., 2018; Ianoş, 2004; Simion, 2016) that cause long term effects inside these ones, as shrinking, ageing, decrease of the working population (Ianoș, 2004; Zamfir, 2007; Pivodă, Boarcăș, 2009; Suditu et al., 2016; Ianoș, 2016; Stasac et al., 2016; Cercleux et al., 2018; Merciu, Ianoş, Cercleux, 2018) or loose of the local identity (Bănică, Istrate, 2012), linked in the same time to important socio-economic transformations.

1 University of Bucharest, Faculty of Geography, Department of Human and Economic Geography, Interdisciplinary Center of Advanced Research on Territorial Dynamics, E-mail: loreta.cercleux@geo.unibuc.ro,cristina.merciu@geo.unibuc.ro

2 University of Bucharest, Faculty of Geography, Department of Human and Economic Geography, E mail: elena.bogan@yahoo.com

3 University of Bucharest, Faculty of Geography, Department of Geomorphology, Pedology and Geomatics, E-mail: george.merciu@geo.unibuc.ro 
Small and medium-sized towns are generally characterized by a more industrial profile than bigger towns and cities. The interpretation of small and medium-sized towns is different at international level. In European scientific literature and territorial politics, the definitions are relying on vague criteria which make difficult the finding of a common definition. In most of the cases, the characterization of small and medium-sized towns depends, in general, on the national urban hierarchies and the role and weight of towns in the local or regional economy. European small and medium-sized towns are defined and analysed in ESPON TOWN project. According to this project, the population in small and medium-sized towns varies from one country to another, ranging from 5,000 to 100,000 inhabitants (Servillo et al., 2014) and the towns are considered in relation with three complementary approaches: administrative, morphological and functional (Servillo, Atkinson, Hamdouch, 2017). In many researches from the 1970s and 1980s, small and medium-sized towns were analysed relying firstly on their demographical potential or trends of their dynamic's population (Champion, 1998) and deindustrialisation process (Demazière, 2017). Once the loss of industry became more evident and the first economic consequences started to appear, other research topics came into focus when analysing small or medium-sized towns in general or in certain areas, among which the most recent are: the challenges and solutions for their development (Popescu, 2007; Cercleux, Merciu, Merciu, 2012; Jucu, Pavel, 2018), towns as elementary vehicles for balanced prosperity (de Noronha, Vaz, 2015), location and proximity of small towns in relation to metropolitan areas (Bański, Czapiewski, Górczyńska, 2016), socio-economic performance of small and medium-sized towns (Sykora, Mulicek, 2017; Meili, Mayer, 2017; Kaufmann, Meili, 2019), development of employment towards business centres or bedroom communities (Kaufmann, Wittwer, 2019), changes in the local labour markets of small towns (Dumitrescu, 2008; Czapiewski, Bański, Górczyńska, 2016), creativity as a driver for small and medium-sized towns` development (INTELI, 2011) and participatory procedures for better understanding the needs of small and medium-sized towns (Pascariu, Pascariu, 2013; Holuj, 2016).

The article focuses on the nowadays demographical features of the Romanian small and medium-sized towns with an industrial footprint (so called small and medium-sized industrial towns or SMITs) that evolved in the last 30 years under the changes brought by the capitalist economy and globalization. We considered as SMITs the Romanian towns with a share of the active population of over $50 \%$ and a population of up to 100,000 inhabitants as in results from the 1992 census. This reference year was chosen because it represents the first national census after the fall of the communist regime in 1989 and reflects accurately the potential of the industrial labour force, still main economic activity of Romania at the beginning of the 1990s. 


\section{General context of evolution of SMITs}

Three industrialization stages of the Romanian towns and cities can be identified in the second part of the $X^{\text {th }}$ century (Ianoş, 2004, pp. 25-26): a) the industrial development stage of the regional centers mainly and the creation of new specialized industrial cities (1950-1970), characterized by cutting the territory into 16 regions and more than one hundred districts (following the Soviet model of administrative organization) and the development of regional residence centers as main growth poles, which benefited from important investments in the industrial and housing sectors; b) the stage of large-scale industrialization of county and mid-city centers (1970-1980), which implied an industrialization policy at the medium-sized towns level. Many of them became county coordination centers after the 1968 reform, the year of the administrative-territorial reorganization in Romania, through the construction of a single industrial enterprise (or the gigantic expansion of one of the older enterprises). The most frequent specializations were in the mining, machine building and chemical industries; c) the industrialization of small towns and rural settlements meant to become agro-industrial centers (1980-1989) has emerged since the 1970s, but evolved especially in the 1980s, characterized by the establishment of at least one large industrial enterprise in the small towns and of other medium-sized ones in the future agro-industrial centers (mainly through the decentralization of large industrial units from the cities and the inauguration of some production sections in the rural areas that were to become urban centers).

The transition to capitalism started in 1990 meant from an economic point of view the beginning of the deindustrialisation process. This reverse economic process, more visible for SMITs with specialized industrial and agricultural functions, evolved in the context of private property and together with the development and diversification of tertiary activities, a sector relatively neglected before.

\section{Methodology}

The paper is analysing the industrial small and medium-sized industrial towns, defined as all the towns from national level with a share of the active population in industry of over $50 \%$ and a population of up to 100,000 inhabitants, according to the census from 1992. In order to analyse the demographic transformations, a series of indicators were calculated, using statistical data from Tempo on-line database of the National Institute of Statistics: natural balance, net migration, ageing population and demographic dependence rate. For all indicators, comparative analyses were performed by 
using data collected and processed for two years (1992 and 2014), except for the net migration situation, presented only for 2014. The statistical data processing was followed by the cartographic representation using the Geographical Information System software.

\section{Results and discussion}

As a geographic distribution, SMITs have a balanced spread in all the country's areas, as a proof of the industrialisation policy that followed a harmonious economic development of all regions. After 1990, especially the small towns with high shares of people employed in the industry sector previously faced a long road of industrial decline: for example, the towns that in 1992 had a share of the active population of about 60-70\% employed in industry, they were facing in 2014 serious economic issues due to the closure of their main industries: in Motru from Gorj county, the coal mine is nowadays closed, in Moldova Nouă from Caraș-Severin county, the copper mine is closed, in Cavnic from Maramureș county, the complex mining - gold, mine, copper, lead and zinc is currently closed. The same situation can be found in the SMITs with a share of the population included in the range of 70-80\%: for example, Aninoasa and Petrila, from Hunedoara county, where the coal mines are at present closed.

This significant difference might be explained through the fact that throughout the communist period, it was intended to emphasize the extraction of the underground natural resources in new extraction wells that played a very important role in the explosive growth in the number of towns on the country's map; in general, there were small towns, specialised only in mining (monoindustrial ones), but also towns with double or multiple functions in the light and heavy industry sector (Ianoș, 2004).

The Romanian industry is facing nowadays significant mutations in terms of functionality of SMITs, following the disappearance of the industrial activities, in general. Interestingly, the decline of the dominant industry in a town determined over the time also the decline of the other existing industries, because the development of the industrial specialisation during the communist period was performed following the principle of proximity of the raw materials supply, but also of the retail market: for example, in the town of Bicaz (Neamt county), the decline of the construction materials industry had a negative impact over the construction sector; in Făgăraș (Brașov county) the diminishing of the production in the chemical industry led to a decline in the chemical equipment construction activities.

In order to analyse the transformations inside the population of Romanian SMITs, for indicators were calculated (natural balance, net migration, ageing 
population and demographic dependence rate) and analysed in most of the cases comparatively, 1992 and 2014.

\section{Natural balance}

In 1992, the values of the natural balance were quite dispersed (Fig. 1), reaching a maximum of $12.07 \%$ in the case of Mioveni town (Argeș county) and a minimum of $-6.85 \%$, registered by the town of Tăuții-Măgheruș (Maramureș county). This indicator, reflecting the evolution of birth and mortality rates, draw mostly attention to the demographic decline.

Towns with moderate negative values (between $-6.1 \%$ and $0 \%$ ) represent a large group (Fig. 1). In this category, there are included 31 SMITs from different regions of the country. In the SMITs located in the Western part of the country, the values are not very high because the population ageing process started earlier compared to other areas at national level.

At the opposite pole, towns with high values of a positive natural balance are characterized by a large proportion of the young population and a wide industrial profile: Mioveni, Motru, Bălan, Uricani, Hârlău, Podu Iloaiei, Târgu Frumos, Vicovu de Sus (Fig. 1).

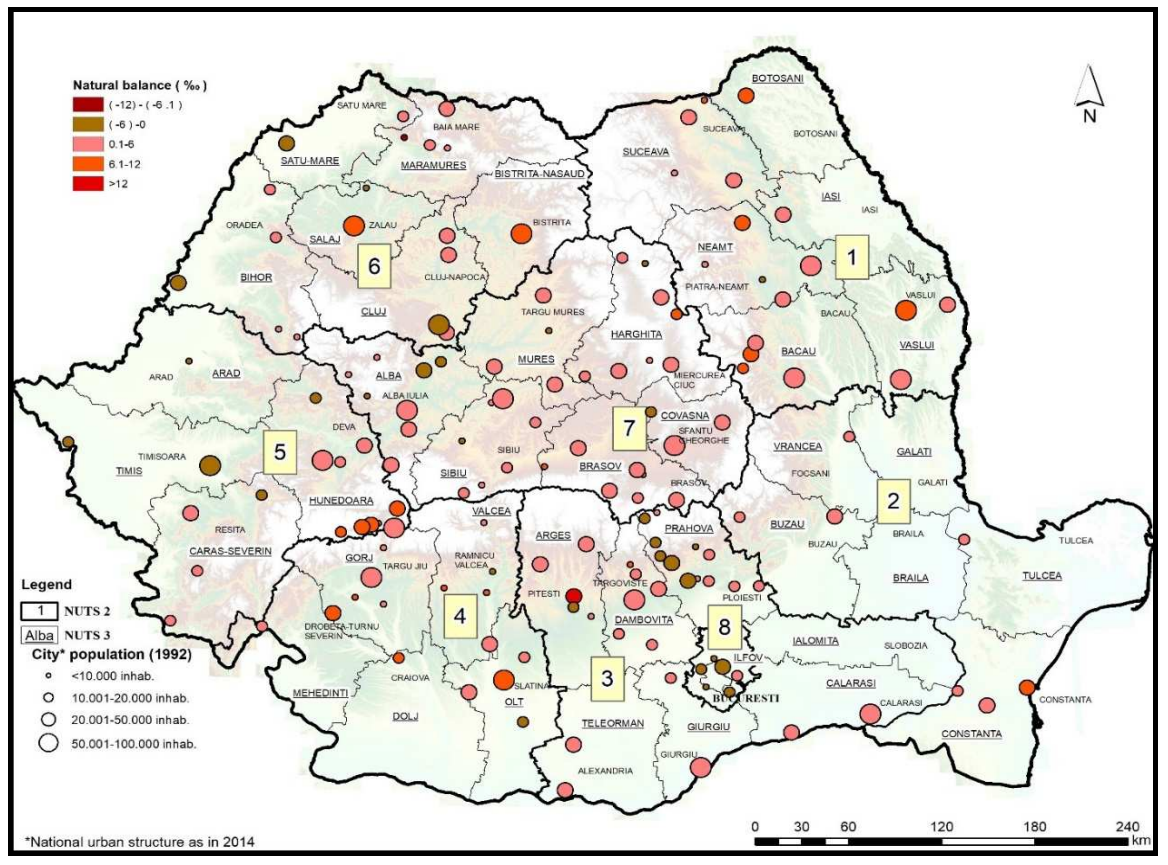

Fig. 1. Natural balance in SMITs (1992) 
The analysis of the natural balance values in 2014 (Fig. 2) reflects an increase of the share of towns that recorded negative values. High negative values, between $(-10 \%)$ and $(-5.1 \%$ ) , characterise 11 SMITs in 2014 compared to only 1 SMIT in 1992 that registered $-6.85 \%$.

Negative values of this indicator are found in many regions, including the North-Eastern part of the country, an area that has previously recorded a positive natural dynamic (Botoşani and Bacău counties). In the central part of Romania, 2 towns registered negative values of the natural balance: Ocna Sibiului (Sibiu county, where during the communist times operated a factory of stainless-steel cutlery and medical instruments and a dairy factory) and Borsec (in Harghita county and known, in the past but also in the present, for bottling of mineral waters and as a balneoclimateric resort).The SMITs that recorded moderate negative values of the natural balance in 2014 are widespread at national level. There is 2.3 times increase in the number of towns with moderate negative values in 2014 compared to 1992. This deterioration of the demographic situation has several causes, among which the most frequent are the population ageing (involving both a mortality rate and a decrease in birth rates) and the changing of demographic behaviour (through late fertility and a decrease in the number of births). In addition, the lack of a real demographic policy at national level has led to a general drop in the birth rate in urban areas.

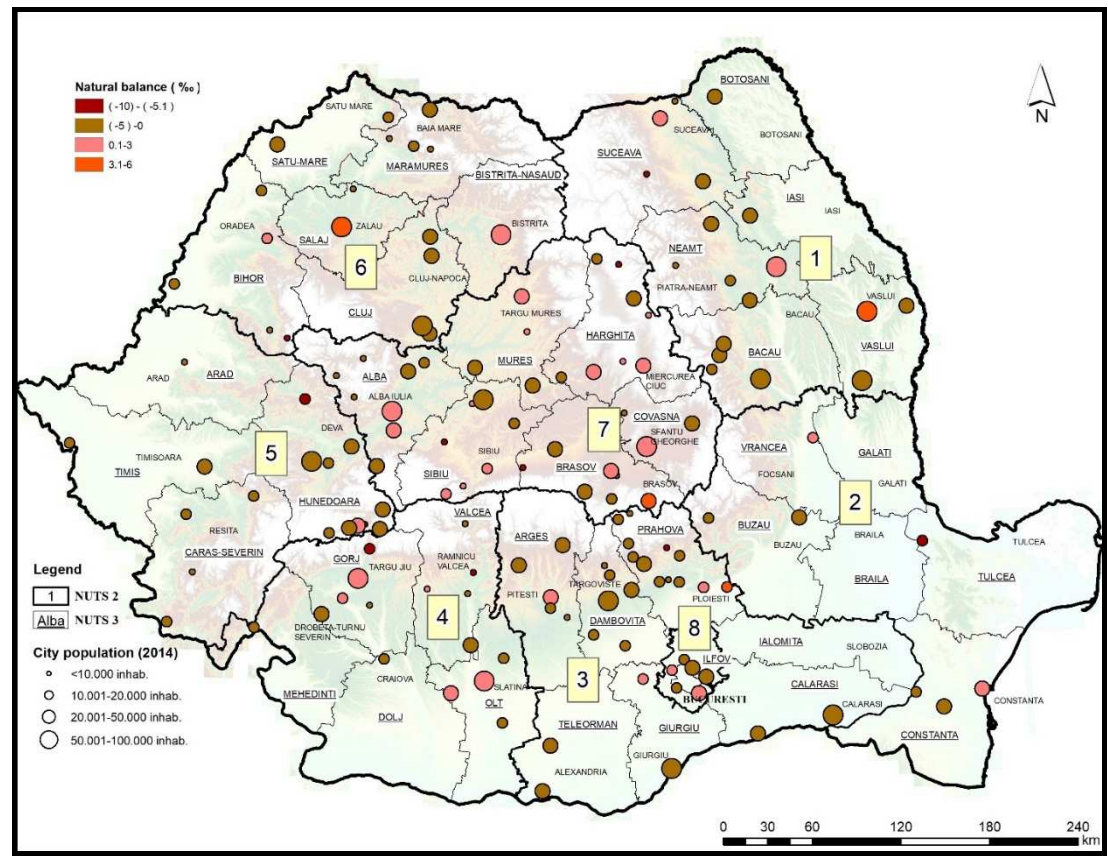

Fig. 2. Natural balance in SMITs (2014) 
This category of towns has a higher spatial distribution compared to 1992 as the number of settlements with moderate negative values has increased, as well as in the North-East region (towns located especially in Bacău, Botoşani and Suceava counties). There is also an increase in the number of towns with moderate negative values of the natural balance located in the central part of the country (predominantly in the Alba, Braşov, Sibiu and Mureş counties). In the Western part of the country, the large share of towns with moderate negative values of the natural balance is explained by the ageing population. In the Southern-Western part of Romania, the increase of the number of towns with moderate negative values of the natural balance is a consequence of the decline of the birth rate in the recent years within industrialized counties due to the industrial restructuring process and because of the medium mortality rates (Caraș-Severin and Hunedoara counties). A concentration of SMITs with moderate negative values of the natural balance is located in the development regions in the Southern part of the country as a result of the birth rate decline in the towns with agricultural functions (from Dolj, Olt, Teleorman, Constanța and Brăila counties), or because of the high mortality rates of the urban centers declared after 2000 (from Ilfov and Mehedinţi counties).

A lower natural deficit (between $-1 \%$ and $0 \%$ ) register Moreni $(-0.52 \%$ ) and several towns located in the North-East Region: Pașcani $(0.28 \%$ ), Fălticeni (0.32\%o), Dorohoi (-0.30\%o), Dărmănești: $(-0.40 \%$ o).

In conclusion, it can be appreciated that SMITs with a population less than 25,000 inhabitants are characterized by a descendent evolution of the natural balance, with some temporal and spatial differences. This decline is in line with the general national trend, but the numerous negative values recorded in the second part of the analysis period show that small and medium-sized industrial towns have entered a demographic decline that could be redirected only through economic development and by attracting new young people inside these areas.

If in 1992 the negative values of the natural balance already characterized a large part of the small and medium-sized industrial towns from Banat and Transylvania, in 2014 , for the first time, the negative values characterized also the SMITs from Moldova region, an area considered as a traditional demographic behaviour favourable to high birth rates.

SMITs that registered a positive natural balance are in general towns that benefited from inflows of young population before 1990 due to newly developed industrial activities or are settlements with an important share of Roma in the total population. 


\section{Net migration (including external migration)}

The net migration analysis (including the external migration) was analysed only for 2014 and reflects a number of spatial differences. The towns with the highest negative values of net migration rate are, in general, towns that were confronted with an important decline of the local industry. In most of the cases it is about mining towns and machine building industry. More than 100 SMITs register negative values, between $-12 \%$ and $0 \%$. Under the impact of deindustrialisation, the labour migration produced in three successive forms: 1) towards the nearby rural areas; 2) to larger cities from the same county or region; 3) abroad, mostly to West European countries.

On the other hand, some industrial towns, especially medium-sized towns, have experienced population arrivals. These are towns characterized by a continuity in the traditional industrial activity in wood, machine building and light industry, but organised inside industrial parks and clusters starting with the second part of the 2000s.

The number of arrivals was more important in 2014 in Ghimbav, an urban center specialised in aeronautical industry that continued to develop in the capitalism times and in towns near Bucharest, like Otopeni, Voluntari, Chitila, Popești-Leordeni or Bragadiru (Fig. 3). These towns developed important tertiary activities and gained population due to the intensification of the suburbanization process. There is also an example of false increase of population: Vaslui town has a net migration rate of almost $101 \%$, but it is only a statistic growth; the situation can be explained by the fact that citizens from the Republic of Moldova have obtained Romanian citizenship and domicile in Vaslui town (Merciu, Ianoș, Cercleux, 2018). The largest loss of SMITs' population is registered by the towns with extractive or heavy industries: Cugir (armament and metal processing industry, two activities which reduced in a large share their importance in the present), Ocna Mureş (with soda and tobacco productions in the past), Câmpulung (with former machine building industry), Hunedoara (mettalurgy), Motru and Petroșani (coal industry). 


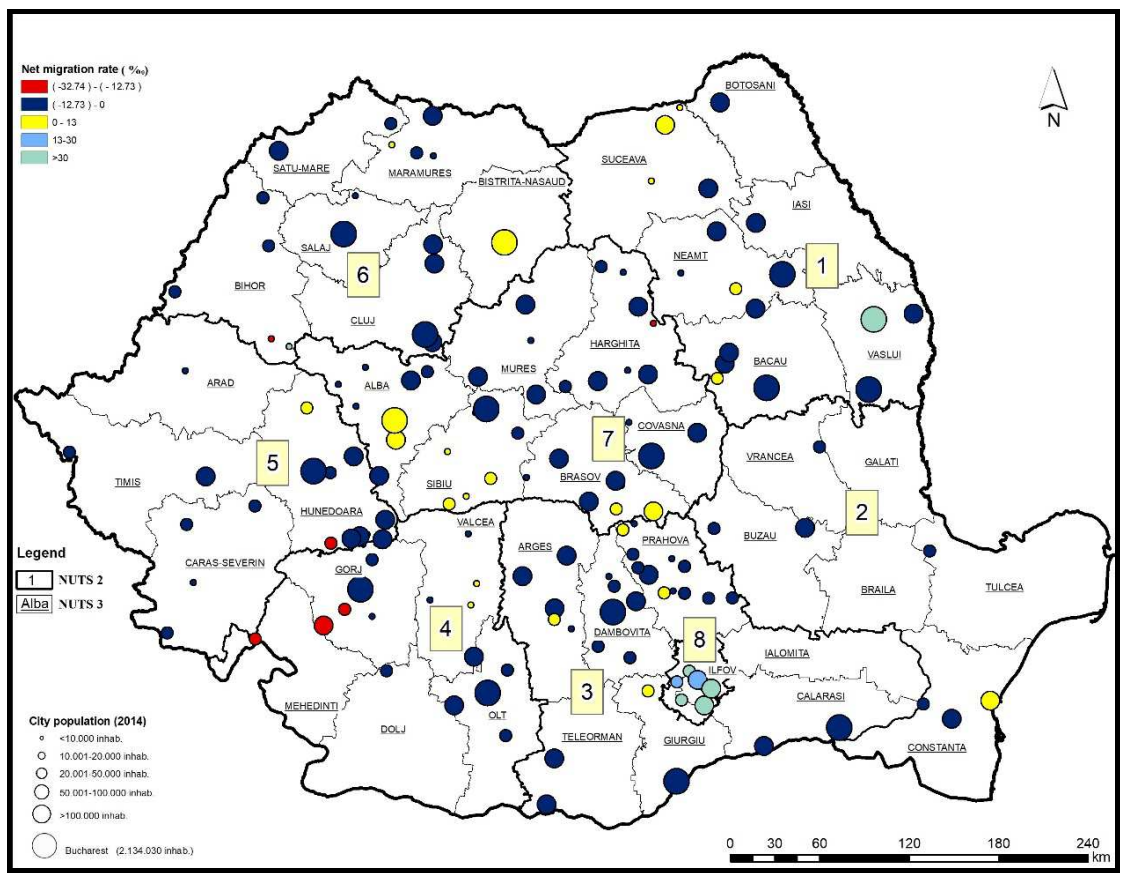

Fig.3. Net migration (including external migration) in SMITs (2014) Source: Merciu F.-C., Ianoș I., Cercleux A.-L., 2018, with changes

Most of the small and medium-sized industrial towns have lost their population both on the basis of internal migration (predominantly oriented towards the polarizing cities) and of external migration (as non-qualified workforce).

\section{Ageing population}

Regarding the phenomenon of ageing population inside small and medium-sized industrial towns (Fig. 4 and 5), almost $10 \%$ of the total number of SMITs registered in 1992 values below 5\% of population over 65 years old in the total population, compared to only 2 SMITs in 2014, towns where the industry is still functional: Rovinari (Gorj county, coal industry) and Mioveni (Arges county, machine building industry - Dacia Plant). Thus, most part of these towns were confronted during the two last decades to increases of the elderly population that places them in 2014 in superior categories: $5.1-10 \%$ and $10.1-15 \%$. 


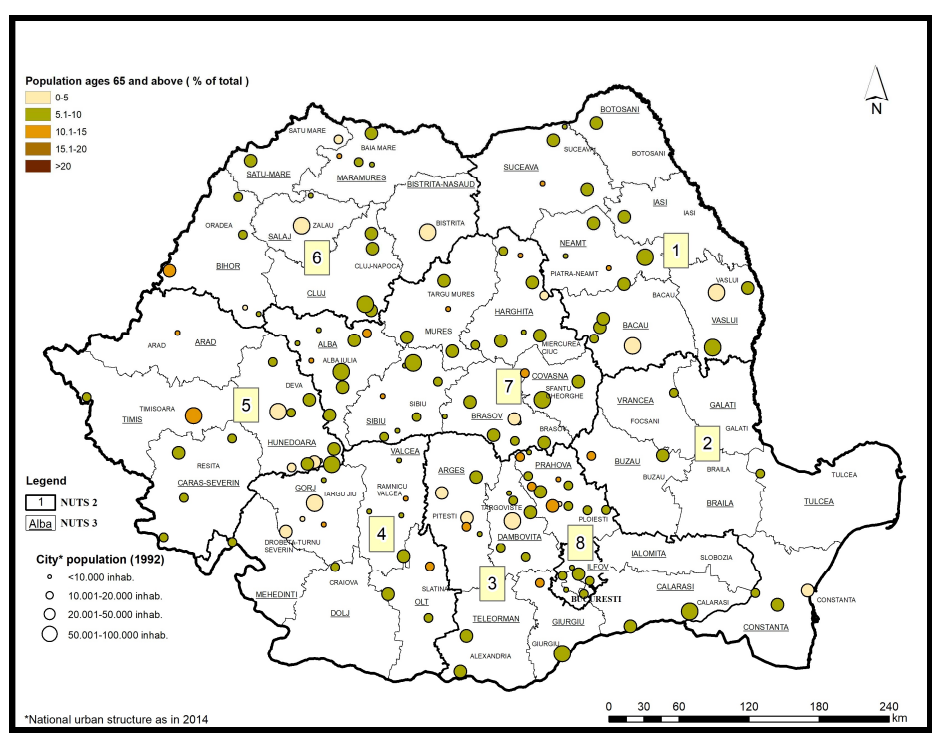

Fig. 4. The ageing population in SMITs (1992)

Also, in the context of a visible increase in the share of the elderly population in 2014 compared to 1992, the immediate upper category, 5.1-10\%, is less common because almost all these towns have moved to a higher category, $10.1-15 \%$.

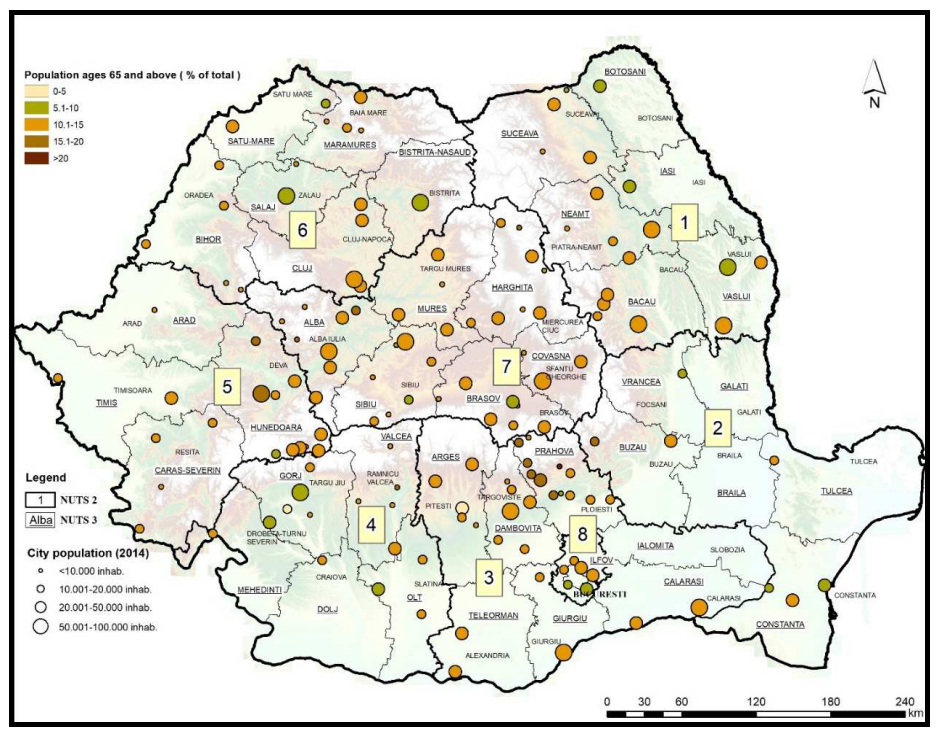

Fig. 5. The ageing population in SMITs (2014) 
The national average of the population over the age of 65 in the total population has increased to $13 \%$ in 2014 compared to almost 9\% in 1992. The rise in the elderly population can be attributed to several changes brought by the transition to the market economy. On the one hand, these are global changes, such as: the gradual decrease of birth rates in the urban environment; the significant reduction in mortality rates over time and, implicitly, the increase in average life span due to medical progress; the quality of life increasing; the development of social protection policies, etc.

On the other hand, the phenomenon of demographic ageing in Romania is influenced by changes in the economic sector at national level, which have affected the balance between generations: the closure of industries in small and medium-sized mono-industrial towns, but also in those whose economies were mainly based on several industrial specializations, led, firstly, to the increasing of the unemployment among the active population close to the retirement age and, then, to the younger active population; this phenomenon has contributed to the intensification of the internal migration of the active young population to the larger cities within the county or even to cities that were at longer distances in search of new jobs and the return of the elderly to a rural life; the external migration of the young active population after 2007, the year of Romania's accession to the European Union, has accelerated this phenomenon. Other causes were: the 2008 economic crisis; the delays in applying economic recovery plans in the towns affected by the closure of the industrial units; insufficient projects for the modernisation and rehabilitation of the technical and municipal infrastructure within small and medium-sized industrial towns.

Although the phenomenon of demographic ageing is less pronounced in the urban environment as opposed to the rural one, it remains a long-lasting phenomenon that is taking place in the context of the drop in the number of active people in the urban population and the negative consequences are increasingly visible in terms of economic and social issues: labour market disruptions by diminishing the number of young active population and by increasing the number of elderly people who either continue to participate in the economic activity or retire; changes in the quality of life; increasing poverty, etc.

\section{Demographic dependence rate}

The effects of the ageing population on the development of social and economic life, but also on the demographic evolution perspectives are also underlined by the situation of the young and the elderly population demographic dependence.

Even if the analysis of Fig. 6 and 7 shows that the demographic dependence is higher in 1992 than in 2014, the situation is different for the two years in terms of the age categories participating in the registered values. In 
1992 , the share of the young population, under 15 , is the one that explains the values below 53\% for some SMITs or over $60 \%$ in the towns from the North-East Development Region, where the highest birth rate is registered. An important role was played by the pro-birth policy promoted by the totalitarian regime after 1967. In 2014, the share of elderly people over 65 years old generally contributes to the high levels of demographic dependence, but there are also cases of small towns where the ageing population is softened by maintaining high birth rates. Inside the Romanian SMITs the population ageing situation is less worrying in 1992 than in other cities, most of them with values below $10 \%$. Higher values are recorded, up to $15 \%$, in the western part of the country, especially due to the emigration of the German population after 1990, usually active population: Pâncota (Arad county), Salonta (Bihor county) or Lugoj (Timiș county).

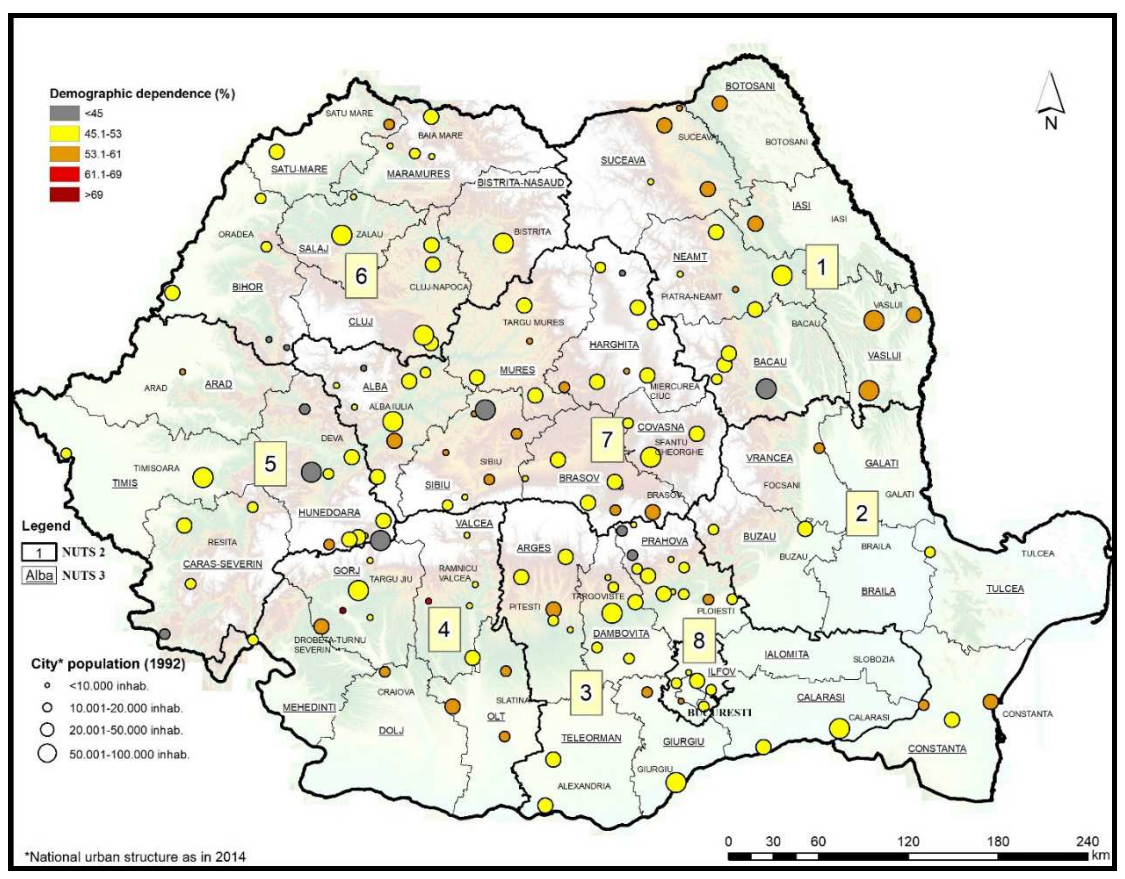

Fig. 6. The demographic dependence rate (1992)

Also, high values of elderly population are found in the urban centers from Prahova Valley, as a result of the deindustrialisation process that began immediately after 1990: Băicoi (oil industry), Azuga (various industrial branches: textile, glass and beer) and Comarnic (cement), as well as the purchase of dwellings in this tourist area, the most recognized at national level, in a large percentage by retirees (from Bucharest, Brașov, etc.). 
In 2014, the image of SMITs is similar to the other cities at national level, in the sense that for those that recorded a value below $10 \%$ of the population over 65 years, in 2014 values are up to $15 \%$. The same situation is also registered in the next upper category, with increases from $15 \%$ to $20 \%$ of the elderly population in the total population.

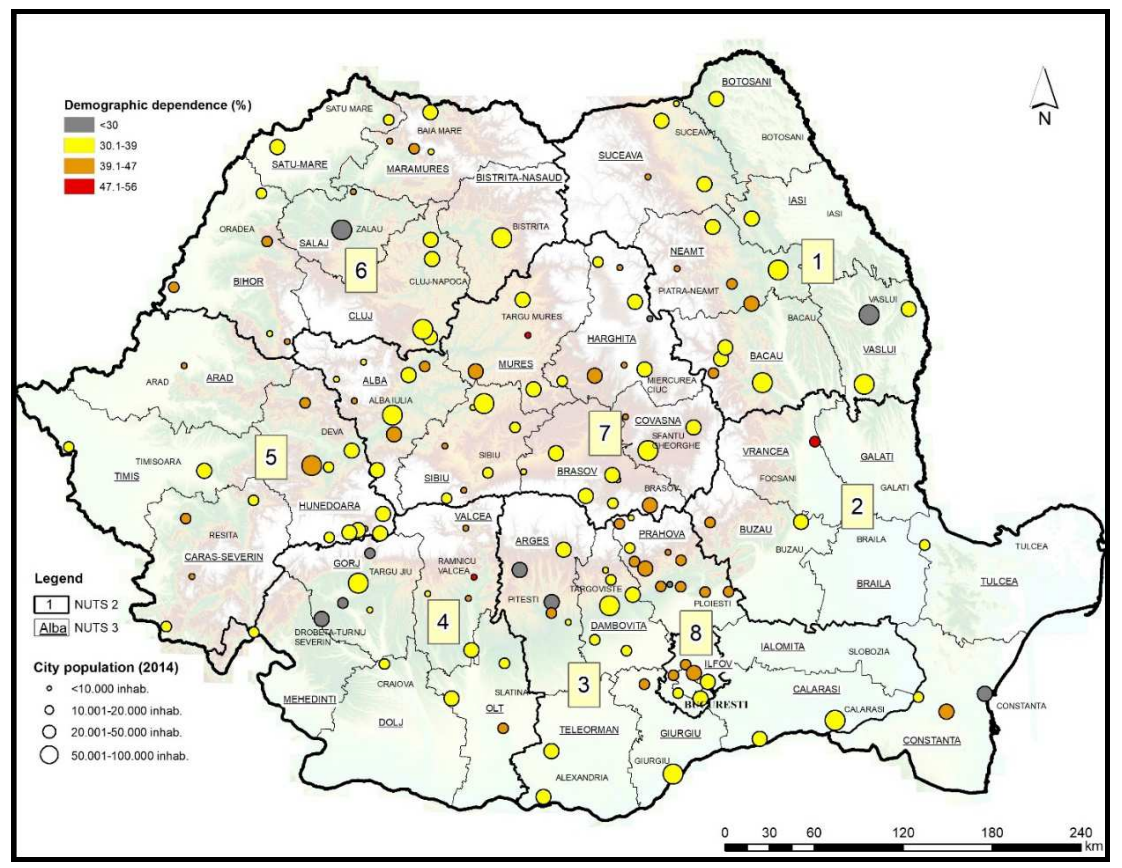

Fig. 7. The demographic dependence rate (2014)

\section{Conclusions}

This analyse of the population evolution in the last decades highlights the fact that Romanian SMITs are vulnerable settlements, mostly in different states of regression. The general demographic decline is due to the diminution of the birth rate and to the mass workforce migration. Only some SMITs resisted, respectively those that have attracted massive investments in already existing activities (as Mioveni where Dacia Plant is located, with a revitalized car industry, but with a drastic cut in number of employees) or in new ones. Small and medium-sized industrial towns lost progressively population in favour of the rural environment, bigger cities and, then, abroad. The reasons that drove migration were mainly the need for work and, for members of different communities, the return to their countries of origin. These departures of 
population gave rise to other phenomena, such as different forms of poverty, territorial degradation, processes of periphery, disparities and inequalities. Few SMITs are demographically winning, as towns with good economic development in recent years or those situated in the proximity of Bucharest and big cities that favours the attraction of inflows of young population. Unfortunately, a large share of SMITs are shrinking towns, facing not only socio-economic dysfunctions, but also socio-spatial fractures. The most probable scenario is of continuous demographical decline, in line with the trend of Eastern European countries (EUROSTAT, 2019) and with repercussions on the loss of local identity specificity.

\section{Acknowledgment}

This work was supported by a grant of the Romanian National Authority for Scientific Research and Innovation, CCDI-UEFISCDI, project number 69/2017 COFUND-ENSUF-BRIGHT FUTURE, within PNCDI III and the research project „Urban Restructuring in Small and Medium Sized Industrial Towns from Romania” (UB 3362/2018).

\section{BIBLIOGRAPHY}

Antonescu, D., Popa, F., 2012, 'Growth and decline of urban areas in Romania', Romanian Journal of Economics, vol. 34, no. 1, pp. 131-156.

Bański, J., Czapiewski, K., Górczyńska, M., 2016, 'Impact of the locations of small towns in Mazovia (Poland) on their socio-economic structure and on their role in relation to the neighboring rural areas', Journal of Urban and Regional Analysis, vol. VIII, no. 2, pp. 117-131.

Bănică, Al., Istrate, M., 2012, 'Urban identities in peripheral spaces: the Carpathian small towns in Romania', Annals of the University of Oradea, Series Geography, vol 22, no. 2, pp. 262-272.

Cepoiu, A.-L., 2009, Rolul activităților industriale în dezvoltarea așezărilor din spațiul metropolitan al Bucureștilor, Universitară Publishing House, Bucharest.

Cercleux, A.-L., Merciu, F.-C., Merciu, G.-L., 2012, 'Models of technical and industrial heritage re-use in Romania', Proceedings of Conference Landscape, Environment, European Identity, Procedia Environmental Sciences, vol. 14, 216-225, Elsevier, November 04-06, 2011, Bucharest.

Cercleux, A.-L., 2016, Dinamica spațiului urban, Universitară Publishing House, Bucharest.

Cercleux, A.-L., Merciu, F.-C., Bogan, E., Florea-Saghin, I., Paraschiv, M., 2018, 'Industrial restructuring in small and medium sized towns from Romania - evolution, background and positive perspective with challenges', Annals of the University of Oradea, Series Geography, vol 28, no. 2, pp. 197-209.

Champion, A., 1998, 'Les tendances démographiques des villes petites et moyennes en régions non métropolitaines', Revue de géographie de Lyon, vol. 73, no1, Varia. pp. 5-16, doi: https://doi.org/10.3406/geoca.1998.4798; https://www.persee.fr/doc/geoca_0035-113x_19 98_num_73_1_4798, viewied 20 July 2019. 
Ciommi, M.T., Zambon, I., Salvati, L., 2019, 'Population dynamics, agglomeration economies and municipal size: a long-term analysis', Journal of Urban and Regional Analysis, vol. XI, no. 1, pp. 5-17.

Czapiewski, K., Bański, J., Górczyńska, M., 2016, 'The impact of location on the role of small towns in regional development: Mazovia, Poland', European Countryside, vol. 4, pp. 413-426.

Demazière, C., 2017, 'Le traitement des petites et moyennes villes par les études urbaines', Espaces et sociétés, vol 1, nr. 168-169, pp. 17-32, https://www.cairn.inforevue-espaces-etsocietes-2017-1-page-17.htm, viewed on 20.07.2019.

De Noronha, T., Vaz, E., 2015, 'Framing urban habitats: the small and medium towns in the peripheries', Habitat International, vol. 45, part 2, pp. 147-155.

Dumitrescu, B., 2008, Orașele monoindustriale din România. Intre industrializare forțată și declin economic, Universitară Publishing House, Bucharest.

Holuj, D., 2016, 'Social Participation as a Tool for Managing Functional and Spatial Changes. Examples of Selected Centres of Small and Medium-Sized Towns in Poland', Journal of Settlements and Spatial Planning, vol. 7, no. 2, pp. 113-123, DOI: 10.19188/02JSSP022016.

Ianoș, I., 2004, Dinamică urbană, Technical Press, Romania.

Ianoş, I., 2016, 'Causal relationships between economic dynamics and migration. Romania as case study', in J. Dominguez-Mujica (ed), Global Change and Human Mobility, Series title: Advances Geographical and Environmental Sciences, Springer Press, XXX, Singapore, 249-264.

Jucu, I.S., Pavel, C.S., 2018, 'Identifying industrial heritage of Romanian small and medium-sized towns: two samples from Timiş county of Romania', Annals of the Professional Association of Romanian Geographers, vol. 9, pp. 5-28.

Kaufmann, D., Meili, R., 2019, 'Leaves in the wind? Local policies of small and medium-sized towns in metropolitan regions', European Planning Studies, vol. 27, no. 1, pp. 21-41, DOI: 10.1080/09654313.2018.1535576.

Kaufmann, D., Wittwer, S., 2019, 'Business centre or bedroom community? The development of employment in small and medium-sized towns', Regional Studies, vol. 53, no. 10, pp. 1483-1493, DOI: $10.1080 / 00343404.2019 .1585529$

Meili, R., Mayer, H., 2017, 'Small and Medium-Sized Towns in Switzerland: Economic Heterogeneity, Socioeconomic Performance and Linkages', Erdkunde, vol. 71, no. 4, pp. 313-332.

Merciu, F.-C., Ianoş, I., Cercleux, A.-L., 2018, 'Patterns of migration in Romanian small and medium sized industrial towns', pp. 414-417, Proceedings of the International Scientific Conference: Information Society and Sustainable Development, $\mathrm{V}^{\text {th }}$ Edition, April 27-28, 2018, Târgu Jiu, Romania, Academica Brâncuși Publishing House.

Pascariu, G., Pascariu, S., 2013, 'Integrated urban development through participatory approach. A Romanian story', Romanian Journal of Regional Science, vol. 7, pp. 69-85.

Pivodă, R.M., Boarcăș, C., 2009, 'Yesterday's natality, tomorow's workforce', Annales Universitatis Apulensis Series Oeconomica, vol. 11, no. 2, pp. 678-686.

Popescu, R.I. 2007, 'Challenges and solutions for the development of small and medium sized cities within the European Union', Administrație și Management public, vol. 9, pp. 120-125.

Servillo, L., Atkinson, R., Smith, I., Russo, A., Sykora, L., Demazière, C., Hamdouch, A., 2014, TOWN small and medium sized towns in their functional territorial context, Final report, ESPON.

Servillo, L., Atkinson, R., Hamdouch, A., 2017, 'Small and Medium-Sized Towns in Europe: Conceptual, Methodological and Policy Issues', Tijdschrift voor Economische en Sociale Geografie, vol. 108, vol. 4, pp. 365-379, Special Issue: SI, DOI: 10.1111/tesg.12252.

Simion, G., 2016, 'Effects of postsocialist deindustrialization in Central and Eastern Europe: Results of an industrial site survey and GIS mapping in Bucharest City, Romania', Human Geographies Journal of Studies and Research in Human Geography, vol. 10, no. 1, pp. 79-93. 
Suditu, B., Vâlceanu, D.-G., Neguț, S., Dumitrache, L., Nae, M., Vârdol, D., 2016, 'Using ESDA from studying demographic disparities in Romanian low urban polarization areas', Urbanism, Architecture, Constructions, vol. 7, no. 2, pp. 83-103.

Sykora, L., Mulicek, O., 2017, 'Territorial Arrangements of Small and Medium-Sized Towns from a Functional-Spatial Perspective', Tijdschrift voor Economische en Sociale Geografie, vol. 108, no. 4, pp. 438-455, Special Issue: SI, DOI: 10.1111/tesg.12249.

Stasac, M., Filimon, C., Petrea, R., Bulzan, A., 2016, The demographic behaviour of small towns in Romania in the post-communist period analysed through the dynamics of the population. Case study: the small towns in Bihor county, Romania, Annals of the University of Oradea, Series Geography, vol. 26, no. 2, pp. 210-222.

Zamfir, D., 2007, Geodemografia orașelor mici din Romania, Universitară Publishing House, Bucharest.

*** (2011) INTELI Creative-based Strategies in Small and Medium-sized Cities: Guidelines for Local Authorities, Creative Clusters in low density urban areas.

National Institute of Statistics, Tempo online database

https://ec.europa.eu/eurostat/web/population-demography-migration-projections/publications 